\title{
18-19. Yüzyıllarda Osmanlı Devleti'nde Bazı Müsâdere Uygulamalar1
}

\section{Some Practices of Confiscation in the Ottoman State in the 18-19th Century}

\section{Mebmet Karataş*}

\section{Özet}

Müsâdere: Yasak edilen bir șeyin kanun gereği elden alınması veya suçlu görülen bir kimsenin malının devlet tarafindan zapt edilmesi anlamına gelmektedir. İslâm hukukçuları, yöneticilerin kendi menfaatlerine harcamamak şartıyla devletin koyduğu yasaklar çiğnenerek haksız bir şekilde elde edilen malların müsâdere edilmesini uygun bulmuştur. Osmanlı Devleti müsâdereyi ceza, emniyet tedbiri ve tazmin olarak çokça uygulamıştır. suistimale açık olduğundan birçok keyfî uygulamalara da rastlanmaktadır. Ancak şartlarına uyulduğu taktirde bugün de devlet menfaatine olan bir uygulamadır.

\section{Anabtar kelimeler: Osmanl, İslâm, Müsâdere, Ceza a}

\section{Abstract}

Confiscation is a word which describes state confiscation taken against a person who abused his official duty. According to Islamic jurists, it is legal to confiscate a person's property earned illegally with a condition that the confiscated property should pass into the hands of the state administrators. The practice of Confiscation is adopted and used by the Ottoman State by various reasons such as to punish criminals or to compensate illegally earned state property. This practice at the same time produced some arbitrary implementations because it mussed by state official. However incases Confiscation was to be used by state administration properly and adequately it was useful and beneficial to the state is even valid for today's state practices.

Keys Word: Ottoman, Islam, Confiscation, Punishment 
Devlet adına çalışırken kazanılan malların kamuya ait sayılması kuralına dayanılarak uygulanan müsâdere, başlangıçta zulüm ve irtikâbından şüphe edilen veya serveti ile dikkati çeken devlet büyükleri hakkında diğerlerine de ibret olmak üzere uygulanırken, sonraları böyle bir töhmet söz konusu olmaksızın eceli ile veya idam yoluyla ölenler hakkında da kullanılmaya başland ${ }^{1}$. Müsâdereye maruz kalan memur önce teftiş edilir, paraların yerini söyletmek için bazen hapis ve zorlama gibi yollara başvurulurdu. El konulan para veya malların bedeli beytülmale intikal ettirilir; böylece mirasçllar bu servetten mahrum bırakılırdı. Bu şekildeki bir uygulama ile, kişinin kendi evlatlarına mal bırakma kaygısı olmadan çalışması ve kamuya daha faydalı hizmetlerde bulunması hedeflenmiştir. Devlet, bu şekilde kamu için çalışıp servet bırakmadan ölen devlet memurlarının çocuklarına maaş bağlamış, ayrıca bu yöntemle merkezî otoriteyi tesis etmek ve bu otoriteye rakip olabilecek güçlerin ortaya çıkması engellenmiş ve haksız elde edilen kazançlar da tekrar devlet hazinesine kazandırılmıştır ${ }^{2}$. Bazen yapılan haksız müsâdere uygulamalarından vazgeçmiş ve müsâdere edilen malları sahibi varsa sahibine yoksa varislerine geri ödemiştir.

Bu makalede müsâdere ve meşruiyeti ile ilgili genel bilgi verildikten sonra 18 ve 19. yüzyıllarda Osmanlı Devleti’nin müsâdere uygulamalarından bazı örnekler verilerek, bu tür uygulamaların Yeni Türk Ceza Kanunu'ndaki yeri üzerinde durulacaktır.

\section{1- Müsâderenin Tarifi}

Müsâdere: Arapça bir kelime olup lügatlerde, yasak edilen bir şeyin kanun gereği elden alınması, resmen zapt edilmesi; suçlu görülen bir kimsenin malının hükümetçe padişah adına zapt edilmesi anlamına gelmektedir. Sudûr kökünden "müfâale" vezninde bir mastardır. Çoğulu müsâderât'tır ${ }^{3}$. Devlet görevlilerinin hediye adı altında aldıkları şeylere veya kaçak silâhlara yetkili makamlarca el konulmasi gibi ${ }^{4}$.

${ }^{1}$ Mustafa Nuri Paşa, Netâicü'l-vukêat, Sad. Neşet Çağatay, TTK. Ankara 1992, I, s.309; Cavit Baysun, "Müsâdere", IA; MEB. İstanbul 1993, IX, s.671.

${ }^{2}$ Mustafa Nuri Paşa, a.g.e., s.308; Abdullah Saydam, Osmanl Medeniyeti Taribi, Derya Kitabevi, Trabzon 1999, s.371; Tuncay Öğün, "Osmanlı Devletinde Müsâdere Uygulamaları”, Osmanl, Yeni Türkiye, Ankara 1999, V, s.373.

${ }^{3}$ Ferit Devellioğlu, Osmanlica-Türkçe Ansiklopedik Lügat, Aydın Kitabevi, Ankara 1984, s.879; Șemseddin Sami, Kamus-lTürkî, Çağr1 Yay. İstanbul 1996, s.1355; Hüseyin Özcan, Ansiklopedik Hukuk Sözlï̈̆̈, Alfa, İstanbul 1993, s.567; Ali Şafak, Hukuk Terimleri Sǫ̈lïğ̈̈, Rehber Yay. Ankara 1992, s.380; Abdullah Yeğin, Yeni Lugat, Hizmet Vakfi Yay. İstanbul 1978, s. 495.

${ }^{4}$ Baysun, a.g.m., s. 669; Meydan Larousse, Meydan Yay. İstanbul 1993, IX, s.154. 
Müsâdere terimi tarihte, bazı devlet büyüklerinin veya ülke zenginlerinin ecelleriyle ölmeleri veya suçlu bulunup idam edilmeleri sonucunda geride bıraktıkları mallarına, kimi zaman da sağlıklarında mevcut servetlerine devlet tarafından el konulması anlamında kullanılmıştır. Müsâdere usûlü zaman zaman kötüye kullanılan, zulüm ve işkence aracı yapılan, hatta devletin malî kriz geçirdiği dönemlerde başvurulan bir gelir kaynağı olarak tarihe geçmiştir ${ }^{5}$.

Batıda müsâdere, umûmî olarak, büyük cürümlerin cezalandırılmasında suçlunun mallarının zapt edilmesi, hükümdarların herhangi bir işe ve savaşa girişmesi halinde, zenginlerin malına el konması, ölüme mahkum olanların malları ile mirasçısı olmayan malların alınması şeklinde modern hukûk kurallarının gelişimine kadar devam etmiştir'. Bu yüzden "Osmanlı Devleti'nde Müsâdere" konusuna geçmeden önce "İslâmî Açıdan Müsâdere Yöntemi" üzerinde durmak gerekir.

\section{2- İslâm Hukûku Açısından Müsâderenin Mabiyeti}

Müsâdere İslâm Hukûkunda mahiyeti itibariyle ceza, tedbir veya bedel olarak uygulanabilir. Müsâdere, emniyet tedbiri veya bedel (tazminat) olduğu durumlarda ceza olma özelliği taşımaz. Bazı durumlarda uygulanan müsâderenin ceza, tedbir veya bedel olduğuna hükmetmek kolay değildir. Bazen müsâdere bünyesinde bu üç özellikten birkaçını aynı anda toplayabilir?

\section{a- Müsâderenin Ceza Olarak Uygulanması}

Müsâdere, bulundurulması ve kullanılması serbest olan mallara uygulandığ1 zaman ceza olma özelliği taşır. Bu tür müsâderenin amacı, suçluyu malını alarak cezalandırmak ve caydırıcılıktır. Ceza özelliği taşıyan müsâderenin bir suçla ilişkili olması, müsâdere edilen mal sahibinin fail veya ortak olarak söz konusu suçtan sorumlu olması gerekmektedir.

Müsâdere ceza olarak uygulandığı takdirde bir tür ta'zir cezası olmaktadır. Müsâderenin ta'zir cezası olarak kabul edilmesi, bu husustaki delillere ve maslahat ilkesine dayandırılmaktadır. Müsâdere bir tür ta'zir cezası olması itibariyle, hakimin takdirine göre tek başına veya diğer cezalarla birlikte suçun aslî cezası olabildiği gibi aslî ceza veya cezalar yanında tamamlayıcı ceza olarak uygulanabilir. Müsâdere cezasının korkutucu olması itibariyle çok etkili olduğu hususunda şüphe yoktur. Ayrıca müsâdere cezasının tasfiye amacını da karşıladı̆̆ 1 anlaşılmaktadır ${ }^{8}$.

${ }^{5}$ Baysun, a.g.m., s.671.

"Mehmet Ali Ünal, “Osmanlı İmparatorluğu'nda Müsâdere” Türk Dünyası Araștırmalar Dergisi, Ağustos 1987, S. 49, s.95; Baysun, a.g.m., s. 669.

${ }^{7}$ Hüseyin Esen, "İslâm Hukûku Açısından Müsâdere" , D.E.Ü. İlabiyat Fakülttesi Dergisi, S.XV, İzmir 2002, s.185,186.

${ }^{8}$ Esen, a.g.m., s. 186. 
Ceza olarak müsâdere iki şekilde uygulanmaktadır. 1. Genel müsâdere, suçlunun menkul veya gayri menkul bütün mallarının üstündeki mülkiyetini ortadan kaldıran ve bunları devlete nakleden bir cezadır. 2. Özel müsâdere, yalnız belirli mallara veya mal varlığının belli bir kısmına uygulanır9.

Suçluların suçun işlenmesinde kullandıkları vasıtaların farklılığı ve bu vasıtaların zapt edilip edilmemesine bağlı olarak, bütün suçlulara aynı cezanın uygulanamaması söz konusu olduğundan, genel müsâderede eşitlik ilkesinin ihlalinden bahsedilmektedir. Bu durum müsâdereyi ihtimalî bir ceza yapmaktadır. Zengin bir kişi kendine uygulanan müsâdere cezasından büyük bir acı çekmekle birlikte, mal ve mülkü olmayan, az olan veya borca batmış birisi için bu ceza aynı ağırlıkta değildir. Bölünebilir olmadığından suçlunun ahlakî kötülügüne uydurulabilmesi imkânı yoktur. Ancak eşitlikten maksat vakıada değil, kanun önünde eşitliktir. Diğer cezalarda olduğu gibi müsâderede de sonuç itibariyle bir eşitlik ortaya çıkmamış olabilir.

İşlenen suç ile müsâdere edilen mal arasında uygunsuzluk da söz konusu olabilmektedir. Uyuşturucu taşımacıllı̆ında kullanılan bir geminin müsâdere edilmesi buna örnek olarak zikredilebilir. Bazı hukukçular bu meselenin çözümü için, müsâderenin zorunlu değil, ihtiyarî olarak uygulanması ve her davanın kendi şartları içinde hakime takdir yetkisi tanınmasını teklif etmektedirler ${ }^{10}$.

\section{b-Müsâderenin Emniyet Tedbiri Olarak Uygulanması}

Müsâdere, kullanılması ve tedavülü yasak olan mallara yönelik olduğu zaman bir tedbir olarak uygulanır. Bu mallar uyuşturucu maddelerde olduğu gibi, aslen haram ve yasak olan maddeler ve silahlarda olduğu gibi kullanılmasına izin verilmeyen şeyler olabilir. Bu tür müsâdere, kişinin şahsına değil, söz konusu eşyaya yöneliktir. Bu sebepledir ki sanık ceza almayıp beraat etse veya ölse dahi, bu tür mallar üzerinde müsâdere gerçekleştirilir. Müsâdere konusunun bizzat haram/yasak olan bir mal olması durumunda zorunlu müsâdereden bahsedilecektir. Zira bu çeşit müsâdere "nehy-i ani'l-münker" kötülüğün engellenmesi kabilindendir.

Müsâderenin ceza veya emniyet tedbiri olarak uygulanması arasındaki farklılıklar şunlardır:

a. Ceza olarak uygulanan müsâdere, esasen mülk edinilmesi caiz olduğu halde bir suçla ilgisi bulunan mallar için söz konusu olup, bunda suçluya ac1 çektirme amacı vardır. Emniyet tedbiri olarak uygulanan müsâdere ise mülk edinilmesi ve tedavülü meşru olmayan mallar içindir. Burada bir malın ileride bir suçta kullanılmasını önleme ve bundan meydana gelebilecek tehlikelerden korunma gayesi vardır.

b. Ceza olarak uygulanan müsâdere, ancak mahkemenin zanlı hakkında cezalandırma hükmü vermesi durumunda uygulanır. Emniyet tedbiri olan

${ }^{9}$ Meydan Larousse, IX, s. 154. 
müsâdere ise, bir ceza bulunmasa ve hatta zanlının beraatına karar verilmiş olsa bile uygulanabilir.

c. Emniyet tedbiri olarak uygulanan müsâdere zorunlu müsâderedir. Ceza olarak uygulanan müsâdere ise ihtiyarîdir; uygulanıp uygulanmaması ve uygulama şekli takdire bağlıdır.

d. Ceza olarak uygulanan müsâdere suçlunun veya suçla ilişkisi olanların mal varlığına yönelik olup ilgisi bulunmayan üçüncü şahısların hakkı ihlal edilmez. Emniyet tedbiri olan müsâdere söz konusu eşya zanliya ait olmasa da uygulanır. Zira burada amaç bu tür malların arz ettiği tehlikeyi ortadan kaldırmaktır ${ }^{11}$.

\section{c- Müsâderenin bedel (tazminat) olarak uygulanması}

Müsâdere bazı durumlarda suçun işlenmesinden zarar gören mağdurun zararını gidermek için kendisine verilen bir bedel/tazminat da olabilir ${ }^{12}$.

\section{3- Müsâderenin Meşruiyet Kaynakları}

İslâm'da meşrû yoldan kazanılan servetler koruma altına alınmıştır. Hattâ Ashab-1 Kiram ilk İslâm'a girişlerinde, daha önce müşriklik döneminde kazandıkları servetlerini de muhafaza etmişlerdir. Hz. Peygamber; "Müslüman'ın Müslüman'a kanı, malı ve 1rzı haramdır" buyurmuştur. İslâm toplumunun adaletli olarak uygulanan zekât, öşür, haraç, cizye vb. vergi ve ibadet yükümlülüklerini yerine getirmesine karşılık, devlet de onun malını korumak ve zulümden kaçırmak zorundadır. Ancak, İslâm hukûkunda çeşitli sebeplerle müsâdere yani şahıs mallarına devletin el koyması örneklerine rastlanmaktadir.

1. Küba münafikları, önceleri Küba Mescidinde mü'minlerle birlikte namaz k1lıp dururlarken Ebu Amir isimli bir münafı̆̆ın isteğiyle Dırar Mescidi’ni yapıp kendi cemaatleriyle mü'minlerin arasını açmak istediler. Hz. Peygamber, Dirar Mescidi ile ilgili ayetler nazil olduktan sonra bu mescidi yıktırmıştır. Bu ayet ve daha sonra Peygamberimizin bu konudaki uygulaması bazı eşyaların itlaf suretiyle ortadan kaldırılabileceğinin delili olarak gösterilmiştir ${ }^{13}$.

2. Zekâtını vermeyen kimsenin malının yarısının ceza olarak alınacağını bildiren Behz b. Hakim hadisinin ilgili bölümü şöyledir: "Fakat kim zekâtını vermekten kaçınırsa, şüphesiz biz onu ve malının yarısını Rabbimizin kesin emirlerinden biri olarak alırız. Muhammed'in soyuna ondan bir şey yoktur ${ }^{14}$. Hz.

${ }^{10}$ Esen, a.g.m., s. $186-187$

${ }^{11}$ Esen, a.g.m., s.187-188.

${ }^{12}$ Esen, a.g.m., s. 188.

${ }^{13}$ Kur'ân, Tevbe, 107 vd.; Dırar Mescidi hakkında geniş bilgi için bak. M. Asım Köksal, İslâm Taribi, İrfan Yay. İstanbul 1979, IX, s.251-256; Salih Suruç, Peygamberimizin Hayatı, Yeni Asya Yay. İstanbul 1991, II, s.475-477.

${ }^{14}$ Esen, a.g.m., s. 192. 
Ebubekir'in zekâtını vermeyenlerle savaşı tercih etmesi bu hadise dayanmaktadir ${ }^{15}$.

3. Muaviye İbnu Kurre (R.A.) babasından (Kurre İbnu İyas) naklettiğine göre "Resûlullâh (S.A.S), beni babasının hanımıyla evlenmiş olan bir adama göndererek boynunu vurmamı ve malını müsâdere etmemi emretti." şeklinde rivayet edilmektedir ${ }^{16}$.

4. Hz. Peygamber (S.A.S)'in bir zekât memuruna yaptı̆ğ şu muâmele meşrû müsâderenin ölçüsünü belirlemektedir. Rasûlullâh (S.A.S), Ezd kabilesinden İbnü'l-Ütbiyye adlı bir adamı zekât memuru olarak görevlendirmişti. Memur, görevini yapıp dönünce, malları bir yana koyarak, Hz. Peygamber'e; "Bunlar size ait, şunlar da bana hediye olarak verildi" dedi. Bunun üzerine Allah'in elçisi, ayağa kalktı ve Allah'a hamd ve senadan sonra șöyle buyurdu: "Ben sizden birinizi, Allah'ın bana verdiği yetki ile bir işe görevlendiriyorum. Dönünce; "Bu sizindir, şu da bana hediye verilmiştir" diyor. Bu adam doğru olsaydı, ana babasının evinde oturmakta kendisine hediye verilip verilmeyeceğini görmeli değil miydi? Allah'a yemin ederim ki, sizden kim haksız yere bir șey alırsa kıyamet günü haksız olarak aldığ1 şeyi yüklenerek gelecektir. Kiyamet günü Allah'ın huzurunda birinizin bağıran bir deveyi, bögüren bir ineği veya meleyen bir koyunu yüklenerek geldiğini sakın görmeyeyim". Sonra koltuk altlarının beyazlığı görülecek kadar ellerini kaldırdı ve şöyle buyurdu; "Allahım tebliğ ettim mi? Bunu üç defa tekrar etti"17. Hediye edildiği iddia edilen mallar geri alınmıștır.

5. Hz. Ömer, bir dilencinin yanında ihtiyacının üstünde yiyecek bulunca bunları müsâdere etmiştir ${ }^{18}$.

6. Bunlardan birisi de Ebû Hureyre ile ilgilidir. Halîfe Hz. Ömer (R.A.) Ebû Hureyre'yi Bahreyn bölgesine devlet adına hizmet yapmak üzere göndermiş, bazı şüpheler üzerine daha sonra kendisini azletmiş ve Ebû Hureyre'den on iki bin dirhemi müsâdere edip almıştır. Ebû Hureyre olayı şöyle anlatır: "Ömer beni Bahreyn'e görevlendirdi, daha sonra azletti. On iki bin dirhemi de bana ödetti. Bütün bunlardan sonra beni yeniden göreve çağırdı, ama ben kabul etmedim, Ömer, niçin kabul etmiyorsun? Senden daha hayırlı olan Hz. Yusuf bile kendiliğinden göreve tayin edilmesini istemiștir" dediğinde, ben; "Yûsuf (A.S) Peygamber oğludur, dedesi de, onun babası da peygamberdir. Ben Ümeyye'nin oğluyum, bilmeden bir şey söylerim korkusu içindeyim. Yine bilmeden bir fetva verecek olursam, dayak yemekten korkarım, şerefim

${ }^{15}$ Esen, a.g.m., s. 189; Doğuștan Günümüze Büyük Islâm Taribi, Çağ Yay. İstanbul 1992, II, s.34,35.

${ }^{16}$ Esen, a.g.m., s. 192; Mustafa Avc1, Osmanl Hukûkunda Suclar ve Cezalar, Gökkubbe, İstanbul 2004, s.177.

${ }^{17}$ Zeynüddin Ahmed. b. Ahmed, Sabîh-i Bubârî Mubtasar Tecrîd-i Sarih Tercemesi ve Şerbi, Diyanet İş. Baş. Yay. Ankara 1980, VIII, s. 36,37.

${ }^{18}$ Esen, a.g.m., s. 195. 
lekelenir, elimden malım da alınır" dedim. Ancak burada Ebû Hureyre'nin doğrudan rüşvete tevessül ettiği söylenemez. Akla bile getirilemez. Çalışan kişilerin alacağı hediyeleri Ebû Hureyre "câiz" sanmıştır. Hz. Ömer ise, tüm devlet memurlarının görevleriyle ilgili olarak alacakları hediyelerin "rüşvet" sayılacağ1 görüşünde idi. Bu yüzden Ebû Hureyre'nin bir kısım malını müsâdere etmiştir ${ }^{19}$.

Ömer b. Abdilaziz de hilâfet makamına geçince, daha önce haksızlıkla ve zorla alınan bir takım beytülmal mallarını sahiplerini tespit ettirerek geri vermiştir. İkinci Ömer'in, devlet memurlarının aldığ1 hediyelerle ilgili şu sözü meşhurdur: "Rasûlüllah (S.A.S.) devrinde "hediye" adını alan şey, günümüzde "rüşvet" niteliğine bürünmüştür"20.

7. Hz. Ömer ve Hz. Ali içki satılan bazı iş yerlerini yıktırmışlardır ${ }^{21}$.

Bir çok müctehid yukarıdaki delillere rağmen suçlunun malına el koyarak ta'zîr cezası uygulamanın caiz olmadığı görüşündedir. Çünkü bunda, başkasının malını haksız yere yemek vardır. Ancak Malikî mezhebinden meşhur görüşe, Hambelilere ve Şâfîilerin iki görüşünden birisine ve İbni Âbidîn (ö. 1252/1836)e göre yukarıdaki deliller ve uygulamalar esas alınarak bazı yerlerde mâlî nitelikli ta'zîr cezası olarak müsâdere edilebileceği şeklindedir. Bu müctehidlere göre gayri meşrû yoldan kazanılan mallara ve devlet memurlarının kısa zamanda sebebi bilinmeden artan mallarına yetkililer el koyabilir. Ancak bu el koyma; malların sahipleri bilinir, onlara iade etmek veya beytülmâle koymak amaciyla olursa caizdir. Yöneticiler müsâdereyi kendi israf, lüks ve debdebelerine harcamak veya kişisel servetlerin artturmak için yaparlarsa bu caiz değildir. Bir de müsâdere edilecek malın, haksız olarak ve devletin koyduğu yasaklar çiğnenerek edinilmiş olması da şarttır ${ }^{22}$.

\section{4- Müsâderede Usul}

Malının müsâderesine karar verilen veya siyâseten katledilenin malları hemen tespit edilir. Böylece terekeden mal kaçırma önlenmeye çalışılır. $\mathrm{Bu}$ iş için İstanbul'dan görevlendirilen kimse tarafından gerekli sayıda mübaşir tayin edilir. Ancak bu işin genellikle mahalli kadılarca yapıldı̆̆ı görülmektedir.

Sayıma memur olan kimseler bu işi bazen kolaylıkla yaparlar, bazen de malı müsâdere edilenin akrabaları ve arkadaşları tarafından son derece direnmeyle karşılaşabilirler. Neticede malların bir defteri yapılır ve mallar mühürlenirdi. Bazen siyâseten katl edilenlere ait hiç mal çıkmayabilir. Bu durum da İstanbul'a bildirilirdi. Bazen müsâdere edilmesi gereken malı söyletmek için birçok maddî ve manevî baskı da yapılır. Mallar İstanbul'a geldiğinde tahmin edilenden az

${ }^{19}$ İbn Âbidîn, Reddüll-Mubtâr, Terc. Mehmet Savaş, Şamil Yay. İstanbul 1985, XII, s. 36.

${ }^{20}$ Zeynüddin Ahmed b. Ahmed, a.g.e., s.36,37; Geniş bilgi için bk. Esen, a.g.m., s. 183-

215.

${ }^{21}$ Esen, a.g.m., s. 195.

22i̇bn Âbidîn, a.g.e., XII, s. 34 vd. 
olduğu görülürse geniş bir soruşturmaya gidilirdi. Malı müsâdere edilenin uzak yerlerdeki akrabaları da sorguya çekilirdi. Müsâdere edilen mallar çok kıymetli ise yapılan işleri bizzat padişah takip edebilirdi. Bu yüzden elde edilen değerli mallar padişaha takdim edilirdi. Müsâdere edilen gayr-i menkul mallar arttırma ile satılırdı. Arttırma ile elde edilen para ile müsâdere sonucu ele geçirilen paralar hazineye aktarılırdı. Bu paralar hemen zarûrî olan yerlere harcanırdı. Bu yüzden zarûrete düşüldügü zamanlar padişahlar müsâdereye sarılmışlardır ${ }^{23}$.

\section{Devlet Başkanmm Simrlı Yasama Yetkisi ve Müsâdere}

İslâm hukûkuna göre, içtihadî görüşlerin Kur'ân ve Sünnet normları gibi bağlayıcılıkları yoktur. Bir içtihad, diğer içtihadı nakzedemediğinden biri diğgerinden daha kuvvetli değildir. İçtihatla içtihat nakz edilemez olduğu ve fetvalarla tercih edilen içtihatların da bağlayıcı olmamasından ötürü İslâm hukûkunu tedvin etmek de imkansızlaşmıştır. Bu durum hukûkî hayatta istikrarı zedeleyeceğinden, İslâm hukûkunda devlet başkanına içtihadî görüşlerden birini tercih yetkisi verilmiştir. Bunu, eğer yeterli ise kendisi, değilse ilmine güvenilen hukukçular (şeyhülislâm veya kadılar) yapar. Tercih edilen içtihadî görüşlerin de bağlayıcı bir kanun olabilmesi için, konusu suç teşkil etmemeli ve Şeriata aykırı olmamalıdır. Aksi takdirde tercih edilen görüş geçersiz olur ${ }^{24}$.

Ayrıca, devlet başkanına tefviz edilen ve kendisine şer'î esaslar çerçevesinde kanun koyma yetkisi verilen bazı alanlar vardır. Bu alanları şöylece sıralamak mümkündür:

1- Devlet başkanı caiz olan konularda nizam-1 âlem için kural koyabilir. İslâm hukûkuna göre, "caizde ulül-emrin hakk-1 tasarrufu vardır; Şeriatın menetmediği şeyleri men edebilir". Bu yasama yetkisinin kaynağı; "Allâh’a, O'nun peygamberine ve sizden olan ulü'l-emrin emir ve yasaklarına itaat ediniz" 25 mealindeki ayettir. Osmanlı hukûkunda sultanlar bu yetkilerini yasaknâme adıyla hukûkî düzenlemeler meydana getirerek kullanmışlardır. Yasaknâmeler, devlete ait madenler, tuzlar, para basımı, gümrükler, sabun, hububat gibi ihtiyaç maddeleriyle ilgili nizamlar ve hazineye ait gelirlerin tahsili gibi kamu yararına göre düzenlenmesi devlet başkanına bırakılan konularda kamuya yararlı emir ve yasakları ihtiva etmektedir. Osmanlı hukukçuları, birden fazla evlenmenin şarta bağlanmasını ve küçüklerin velileri tarafindan evlendirilmesinin yasaklanmasını da bu yetkiye dayandırmaktadırlar ${ }^{26}$.

${ }^{23}$ Ahmet Mumcu,Osmanlı Devleti'nde Siyâseten Katl, Birey ve Toplum Yay. Ankara 1985, s.156-158.

${ }^{24}$ Ömer Lütfi Barkan, “Kanun-nâme” $\dot{L}$ A. MEB. İstanbul 1993, VI, s.193; Halil İnalcık, Osmanl İmparatorluğu, Eren Yay. İstanbul 1996, s. 319,320; Yusuf Hallaçoğlu, Osmanlilarda Devlet Teşkilatı ve Sosyal Yapı, TTK. Ankara 1996, s.118-120; Murat Şen, "Osmanlı Hukûkunun Yapısı", Osmanlı, VI, s. 331.

${ }^{25}$ Kur'ân, Nisa 58.

${ }^{26}$ Ahmed Akgündüz, Osmanl Kanunâmeleri ve Hukûkî Tablilleri, OSAV, İstanbul 1990, I, s.74,75; Ünal, Osmanli Müesseseleri Taribi, Isparta 1997, s.95,96. 
2- Devlet başkanı devlete karşı işlenen suçlarla, ta'zir suç ve cezalarını tespit edebilir. Fatih, II. Bayezid, I. Selim ve I. Süleyman'a ait Umûmî Osmanlı kanunnâmelerinin birinci babını oluşturan cezai hükümler, hususi kanunnamelerdeki münferit ve istisnai ceza hükümleri ve Zulkadiroğullarına ait Alâüddevle ve Bozok Kanunnâmelerinin çoğu hükümleri tamamen bu yetki kullanılarak tespit olunmuştur ${ }^{27}$. Esskıya olarak ilan edilen ve haklarında ölüm fermanı gönderilenlerin malları bu yetkiye dayanılarak ya eşkıyalıkları esnasında ya da öldürüldükten sonra müsâdere edilmiştir ${ }^{28}$.

3- Devlet başkanı kamu hizmetlerinin yürütülmesi için idarî, adlî, malî ve askerî düzenlemeler yapabilir. Devletin yapısı ile ilgili idarî düzenlemeler; davaların belirli zamanașımından sonra dinlenmeyeceği veya mahkemelerin altüst şeklinde bir tasnife tabi tutulması gibi adlî düzenlemeler; ordunun teçhizi, eğitim hizmetlerinin yürütülmesi ve sosyal güvenlik kurumlarının ihyası amacıyla tahsil olunan gümrük, cizye gibi şer'î vergilerle bazı örfî vergilerin tanzimi türünden olan malî düzenlemeler; kapıkulu ve eyalet askerleri gibi askeri düzenlemeler hep bu kapsam dahilinde yapılmaktadır. Devlet başkanının bu tür tasarrufları maslahat şartına bağlıdır. Mecelle m. 58, bu hususu "Raiyye yani teb’a üzerine tasarruf, maslahata menuttur" şeklinde formüle etmiştir. Buradaki tasarruf sözcüğü, kamu hizmetlerini yürüten idarî, adlî ve askerî şahısların her çeşit hukûkî tasarruflarını kapsamaktadır²9.

4- Devlet başkanı miri arazi ve tımar nizamı ile ilgili kurallar koyabilir. İslâm hukûkunda devlet başkanına tanınan yasama yetkilerinden biri de, savaş yoluyla fethedilen toprakların hukûkî rejimini ve tasarruf şeklini belirlemesidir. Devlet başkanının bu çeşit araziler üzerinde seçimlik hakkı vardır. Devlet başkanı bu arazileri devlet arazisi yani miri arazi ilan edebilir ve tasarruf şeklini de kamu yararına göre dilediği gibi tanzim edebilir ${ }^{30}$.

İşte müsâdere konusu da değerlendirilirken bu çerçevede değerlendirilirse daha sağlıklı olur. Ancak bu, müsâdere konusunda Osmanlı Devleti ne yapmıșsa hepsi kanunlara uygun olarak yapılmıştır anlamında da anlaşılmamalıdır. Çünkü bir çok konuda olduğu gibi bu konuda da bazen yetkiler çok aşılmış ve zulme varılmıştır.

\section{18.-19. Yǚvnllarda Osmanlı Devletindeki Bazı Müsâdere Uygulamalar}

İslâm devletlerinde, devlet adına çalışırken kazanılan malların kamuya ait

27İnalc1k, a.g.e., s.337,338; Akgündüz, a.g.e., s.75,76; Şen, a.g.m., s.331; Ahmet Mumcu, a.g.e, s.47; Hayreddin Karaman, Mukayeseli İslâm Hukukku, İrfan Yay. İstanbul 1982, I, s.146; Saydam, a.g.e., s.193-296.

${ }^{28} \mathrm{Avc1}$, a.g.e., s. 339 .

${ }^{29}$ Akgündüz, a.g.e., s.76,77; Şen, a.g.m., s.331, 332; Geniş bilgi için bak. İNalcık, a.g.e., s. 319-341.

${ }^{30}$ Akgündüz, a.g.e., s. 77; Şen, a.g.m., s.332: Geniș bilgi için bak. Mehmed Akif Aydın, “Osmanlı'da Hukûk”, Osmanl Devleti Taribi, Zaman Yay. İstanbul 1999, II, s.375-437. 
sayılması kuralına dayanılarak uygulanan müsâdere, 1451'de Fatih Sultan Mehmed döneminde benimsenmiş, ilk defa da 1453'de Çandarlı ailesinin malları müsâdere edilmiştir ${ }^{31}$. Bu uygulamayla yöneticilerin dört temel hedef amaçladıkları anlaşılmaktadır: 1- Önemli rütbelere yükselen kişilerin, ölümlerinden sonra varislerine bir şey bırakamayacaklarını düşünerek dürüst davranmalarını sağlamak 2- Bu yöntemle merkezî otoriteyi tesis etmek ve bu otoriteye rakip olabilecek güçlerin ortaya çıkmasını engellemek 3- Haksız elde edilen kazançları tekrar devlet hazinesine kazandırmak 4- Mali kriz zamanlarında devlete gelir temin etmek ${ }^{32}$.

16. yüzyılda mal varlığının bir kısmının alınmasını içerirdi. Ölen yada idam edilen vezir ve beylerbeylerinin nakit servetleri, değerli eşyaları, silahları, hayvanları ve askeri araç gereçleri kamu adına müsâdere edilirken, emlak ve akar niteliğindeki mirasının büyük bir bölümü varislerine birakılırdı. Önemli bir varlık bırakamadan ölenlerin varislerine devlet tarafindan maaş bağlanırdı ${ }^{33}$.

17. yüzyılda müsâdere uygulamaları daha da yaygınlaştı. Taşra yöneticileri, giderleri karşılamak, sadrazama ve padișaha değerli hediyeler sunabilmek ve kazanç sağlamak için yörelerindeki zenginlere müsâdere uygulamaya başladılar ${ }^{34}$. Hatta bu usul merkezî yönetimce de benimsenmesi neticesinde vezirler ve diğer taşra yöneticileri mallarının ellerinden alınmaması için hileli aile vakıfları kurup bu vakıfların idarelerini kendi soylarına biraktılar. Bunun neticesinde 18. Asırda müsâdere uygulamalarında görülebilir bir azalma meydana geldi35. Ancak ecdadımızın kurduğu vakıfların tamamı malların müsâdere edilmekten kurtarılmak için kurulan vakıflar olduğu söylenemez. Cünkü böyle olsaydı yapılan hayır kurumlarının küçük, bunlara vakfedilen gelirlerin çok daha fazla olması gerekirdi. Halbuki durum tam tersinedir ${ }^{36}$.

Müsâdere ile ilgili incelediğimiz belgelere göre yapılan müsâdere şekillerini birkaç başlik altında toplamak mümkündür.

\section{a. Ceza Olarak Uygulanan Müsâdereler}

Devlet, diğerlerine de ibret olması açısından suçluya diğer bazı cezalarla beraber malını da müsâdere ederek ceza verme yolunu tercih etmiştir.

\footnotetext{
${ }^{31}$ Solak-zâde Taribi, Haz. Vahid Çabuk, TTK. Ankara 1989, I, s.287; Feridun Emecen, "Kuruluştan Küçük Kaynarcaya" Osmanl Devleti Taribi, Zaman Yay. İstanbul 1999, I, s.23; Öğün, a.g.m., s. 374,375.

32 AnaBritannica, Ana Yay. İstanbul 2004, XVI, s.368; Öğün, a.g.m., s. 373.

33 Aynı yer, Mustafa Nuri Paşa, a.g.e., s.308.

${ }^{34}$ Geniş bilgi için bk. Ünal, a.g.m., s103-106; Öğün, a.g.m., s.378.

${ }^{35}$ Hasan Yüksel, Osmanlı Sosyal ve Ekonomik Hayatında V akerflarn Rolü (1585-1683), Sivas 1998, s.20; AnaBritannica, XVI, s.368; Insanlar1 mallarını vakfetmeye iten sebepler konusunda geniş bilgi için bk. Bahaeddin Yediyıldız, XVII. Yüzyılda Türkiiye'de Vakerf Müessessesi, TTK.Yay., Ankara 2003, s.55-82.

${ }^{36}$ Mustafa Nuri Paşa, a.g.e., s.310.
} 
1204/1789 tarihli bir belgede Hasan Paşanın malları müsâdere edilerek vezirliği alınıp Rodos adasına sürgün edilmesi emredilmiştir. Ancak Hasan Paşanın hastalığından dolayı Rodos adasına gitme esnasında çekebileceği zahmet gözönüne alınarak sürgün yerinin daha yakın bir yer olması için görüş sorulmuştur ${ }^{37}$.

1205/1790 tarihli bir belgede iki yüz askerle bizzat hareket etmesi emredilmesine rağmen askerlerini bir başbuğla gönderen Ispartalı Kürt Hasan oğlu Hacı Süleyman'ın sürgün edilerek mallarının müsâdere edilmesi emredilmiş. Ancak Hacı Süleyman ihtiyar olduğundan sürgün edilmeyip sadece mallarının müsâderesiyle yetinilmiştir ${ }^{38}$.

25 Rebiyülevvel 1206/22 Kasım 1791 tarihli bu belgede halka çok zülüm eden Mora Valisi İsmail Paşanın isyanına firsat vermeden yakalanması ve malının zapt edilmesi istenmiştir ${ }^{39}$.

1210/1795 tarihli bir belgede anlaşma hükümlerine uymadan Rusya İskelelerine ruhsatsız gidip gelerek ticaret yapan Bulgar Yergi adındaki bir tüccarın cezalandırılması maksadıyla gemisine el konulmuştur ${ }^{40}$.

Ayrica 3 Receb 1276/26 Ocak 1860 tarihli bir belgede Samsun-Sivas demiryolu yapımı ile ilgili Mösyö Edvar Prayis ile bir anlaşma yapılmış. Ancak Edvar Prayis anlaşma şartlarını yerine getirmediği için anlaşmanın feshedilip Samsun-Sivas demiryolu için verdiği yirmi beş bin Ingiliz Lirası kefalet akçesinin müsâdere edilmesi gerektiği ifade edilmiştir ${ }^{41}$.

1233/1817 tarihli belgede Derviş Paşa halka zulmettiğinden mallarının müsâdere edilmesi istenmiş. Derviş Paşanın durumu diğerlerine ibret olması için bu müsâdere işinin üzerinde ciddiyetle durulması emredilmiştir. Ve eğer Derviş Paşa ihtiyar olmasaydı daha farklı muamele göreceği bildirilmiştir ${ }^{42}$.

Derviş Paşa, ihtiyarlığına acınarak affedilmesi neticesinde halka zulüm ve haksızlıklara devam etmiştir. Bunun üzerine gönderilen 1253/1837 tarihli bir belgede Anadolu Valisi Sâbık Derviş Paşanın aşırı zulüm ve haddi aşması yüzünden vezirliğinin alınarak Kara Hisar-1 Sahib'de ikamete me'mûr edilmesi ve mahalline ulaştı̆̆1 haberi geldiğinde sâirlerine ibret olmak için bütün malları müsâdere olunmak üzere hademeden biri ta'yîn ve mu'temed adamları kimler ise onlar dahi bu tarafa celp ve ihzâr k1lınarak bir habbesi zâyi' ve telef olunmaksızın tahsîline bakılmak üzere mevsimi geldiğinde hâk-i pây-1 hümâyûnı mülûkânelerine arz ve istizân olunarak icrâsına başlanması emredilmiştir. Ayrıca damadı Mehmed Hamdi Efendi de Derviş Paşaya yardımcı olduğundan ifâdesi

${ }^{37}$ BOA. HH, 185/8647

${ }^{38}$ BOA. HH, 194/9551

${ }^{39}$ BOA. HH,104/4091

${ }^{40}$ BOA. HH, 233/13006

${ }^{41}$ BOA. İ.MMS $17 / 748$

${ }^{42} \mathrm{BOA}$. HH, 524/25595 
alınarak tarîk-i tedristen men ettirilip Derviş Paşanın gelecek mu'temed adamlarıla Memhed Hamdi Efendinin de celp ve ihzâr olunması emredilmiştir ${ }^{43}$.

1237/1821 tarihli bir belgede Behram Paşanın uygun olmayan hareketlerinden dolayı Haleb eyâletinin uhdesinden alınarak bir bașkasına verilmesi ve Diyarbekir'e sürgün edilerek oraya vardığında idam edilmesi ve Sivas'daki mallarına ise el konulması istenmiştir ${ }^{44}$.

1283/1866 tarihli bir belgede Rumeli Valisi Sabık Mehmed Paşanın vezirliğinin üzerinden alınması ve Dimetoka'da ikamet etmesi emredilerek bütün mal ve eşyasının müsâdere edilmesi emredilmektedir. Mehmet Paşa Filibe'de elde edilip malları müsâdere edilmiştir. Ancak deftere kaydedilen mallar çok az olduğundan bu hususta Kör Hazine Kâtibi Musa bu valinin gizli mallarını bildiğinden, sorguya çekilmesi gerektiği bildirilmiştir ${ }^{45}$.

\section{b. Emniyet Tedbiri Olarak Yapılan Müsâdereler}

Devlet, gerek kendisinin gerekse vatandaşlarının emniyetini sağlamak için imalı ve kullanılması yasak olan malları müsâdere etmiştir. Şahıslar suçlu bulunmasa da bu çeşit mallar müsâdere edilmiştir.

27 Nisan 1284/9 Mayıs 1868 tarihli bir belgede kaçak tütünün müsâdere edilmesi, ayrıca bu cezanın caydırıcıllı̆ının olması için nakdî ceza da alınması emredilmiştir ${ }^{46}$.

20 Zilka'de 1285/4 Mart 1869 tarihli bir belgede Tüccar Ali Ağanın kanunlara uygun ticaret yapmamasından şüphelenildiğinden İran'a göndereceği şeker müsâdere edilmek üzere gümrükte bekletilmiş. Bu konuda nasıl hareket edilmesi gerektiği sorulmaktadır ${ }^{47}$.

26 Receb 1290/19 Eylül 1873 tarihli bir belgede emniyet gerekçesiyle Mösyö Trigo adındaki tüccarın üç varil lağım fitillerinin müsâdere edildiği bildirilmiştir. Ayrıca lağım fitillerinden birer fiçının Ankara ve İzmit’te kullanılması için izin istenmiştir ${ }^{48}$.

24 Zilka'de 1297/28 Ekim 1880 tarihli bir belgede vatanın ve milletin lehinde neşriyat yapan gazetelerin desteklenmesi gerektiği ifade edilmektedir. Bilakis vatan ve millet aleyhinde zararlı neşriyat yapan başta İttihad ve İstikbâl gazeteleri gibi gazetelere yardım edilmemesi ve bu gazeteler yurt dışında neşrediliyorsa bunların neşrine engel olunması ve yurt içine sokulmaması mevcut olanların ise müsâdere edilmesi emredilmiştir ${ }^{49}$.

${ }^{43}$ BOA. HH, 502/24653

${ }^{44}$ BOA. HH, 469/22908

${ }^{45}$ BOA. HH, 520/25423

46BOA. A.MKT.MHM 381/82

47BOA. A.MKT. MHM 440/70

${ }^{48}$ BOA. A.MKT. MHM 464/46

${ }^{49}$ BOA. Y.A.HUS 165/153 
17 Teşrîn-i sâni 1296/29 Kasım 1880 tarihli bir belgede İbrik denilen Yunan gemisinin aranması neticesinde her torbada onar k1yye olmak üzere yetmiş adet barut torbası ve beylik tüfengi ve kasatura bulunduğundan bulunan malzemeler müsâdere edilmiş ve geminin de ilgili mahalde bulunan karakol gemisine teslim edilmesi istenmiştir ${ }^{50}$.

\section{c. Yapılan Haksız. Müsâderelerden Vazgeçilip Müsâdere Edilen Mallarn İâde veya Tazmin Edilmesi}

Devlet, her zaman haklı müsâderede bulunmamıştır. Yapılan müsâderelerin haksız olduğu anlaşıllnca müsâdere edilen mallar ya aynen iâde edilmiş veya bedelleri tazmin edilmiştir.

1202/1788 tarihli bir belgede Şam Valisi Vezir İbrahim Paşa, Trabluşşam Beylerbeyi ve Cerde Başbuğu Şedid Osman Paşa hakkında önce hapsedip menâsıbının bir başkasına verilerek mallarının müsâdere edilmesi gerektiğini bildirmiştir. Ancak daha sonra yaptığı araştırma neticesinde Osman Paşayı çekemeyenlerin kendisine iftira attıklarını tespit ettiğinden valiliğinin ve başbuğluğunun tekrar üzerinde kalması için müracaat etmiştir ${ }^{51}$.

7 Şevval 1266/16 Ağustos 1850 tarihli bir belgede Piriştine kazası ahalisinden olup Yunan ihtilalinde yaptıklarının cezası olarak küreğe mahkum edilerek malları, silahları ve hayvanları müsâdere edilen kimselerin daha sonra müracaatları üzerine eşyaları, malları ve hayvanları kendilerine iade edilmiştir. Ancak bu arada böyle bir müracaatı olmadı̆̆1 halde altı sene sonra benim de mallarım ve eşyam müsâdere olmuştur deyip müracaat edenlerin bu sözlerinde doğru olmadıkları ifade edilmiştir ${ }^{52}$.

14 Rebiyülevvel 1268/7 Ocak 1852 tarihli bir belgede İngiltere elçisi İbrahim Ağanın yağma edilen malları kendi zimmetine geçirdiğini belirterek bu malları geri vermesi gerektiğine dair istekte bulunmuştur. Bunun üzerine bu mallar geri iade edilmiştir ${ }^{53}$.

26 Rebiyülevvel 1273/25 Kasım 1856 tarihli iki belgede Selanik sekenesinden olup Rum ihtilalinde idam olunan ve Avusturya teb'asindan olduğu kesinleşen Manulaki İbni Civanligi'nin haksız olarak müsâdere edildiği anlaşılan mallarının tazmin edilmesi gerektiği bildirilmiştir ${ }^{54}$.

Yine 19 Ramazan 1273/13 May1s 1857 tarihli bir belgede Avusturya teb'asından olub malı müsâdere edilen Zanogiryako'nun malının tazmini hususunda görevlendirilen ve devletin lehinde iyi hizmetler gören Hariciye Müsteşar1 Nureddin Beğ Efendiye yetmiş beş bin kuruş atiyye verilmesi ve Avusturya Sefareti Müsteşarı Mösyö Raysın rütbesinin üçüncü dereceden ikinci

${ }^{50}$ BOA. Y.RRK.2B.1/67

${ }^{51}$ BOA. HH, 11/3580

${ }^{52}$ BOA. A.MKT. UM 25/49

${ }^{53}$ BOA. H.R.MKT. 42/87

54BOA. A.AMD. 71/70; BOA. A.AMD. 78/30; BOA. A.AMD, 79/63 
dereceye çıkarılması ve diğer Amerikan vatandaşına da dördüncü dereceden bir nişan verilmesine karar verildiği bildirilmiştir ${ }^{55}$.

29 Ramazan 1278/30 Mart 1862 tarihli bir belgeye göre Tepedelenli Ali Paşa ve oğlu Veli Paşanın isyanından dolayı malları müsâdere edilmiştir. Bu arada isyanla ilgisi olmamasına rağmen Tepedelenli'nin torunu olmasından dolayı eski Girit Valisi İsmail Paşa'nın Tırhala'daki çiftlikleri de müsâdere edildiğinden bu çiftliklere karşlık kendisine aylık yirmi bin kuruş maaş tahsis edilmiştir. Ancak sonradan bu maaştan üç bin kuruş indirim yapılmıştır. Bunun üzerine İsmail Paşa çiftliklerinin tekrar kendisine iade edilmesi ile ilgili davada bulunmuş ve devlet onu bu davasında haklı bulup çiftliklerini iade etmiştir ${ }^{56}$.

16 Ramazan 1286/20 Aralık 1869 tarihli bir belgede Merid-zâde Hac1 Mehmed Ağa'nın Tanzimat'tan önce malı müsâdere olunduğu sırada Edremit ve Kemer Edremit'de evlâdına meşrûtan vakf ettiği zeytinlikler dahi padişah ve Bezmialem Valide Sultan Hazerâtı evkaf-1 şeriffelerine ilhak kılındığı cihetle vakfinın fazlasından istifadeleri şart k1lınmış olan evlâtları sefalete düştükleri belirtilmektedir. Bunun üzerine açılan davada torunu Şefik Efendiye beş yüzer diğer dört torununa yüz ellişer ve kızı Ayşe hanıma beş yüzer olmak üzere toplam bin altı yüz kuruş maaş bağlanması kararlaştırılmışıır ${ }^{57}$.

\section{d. Her Müsâdere İsteğine Olumlu Cevap Verilmemiştir}

Devlet, her müsâdere isteğine her zaman da olumlu cevap vermemiştir. Çünkü birbirini çekemeyen insanlar devletin gücünü de arkasını alıp muhâlif gördüğü kimseleri mümkünse ortadan kaldırmak hiç olmazsa zayıf düşürmek için mallarının müsâdere edilmesini sağlamaya çalışmışlardır.

Mesela: 28 Şaban 1277/ 11 Mart 1861 tarihli bir belgede Şam hadisesinde müttehem olanlardan asker için ayrılanların dışındaki kimselerin mallarının müsâdere edilip bu hadisede malları telef olan kimselere verilmesi ile ilgili soruya verilen cevapta bu gibi kimselerin mallarının müsâderesinin caiz olmadığ1 ifade edilmiştir ${ }^{58}$.

3 Rebiyülevvel 1292/9 Nisan 1875 tarihli bir belgede Borokos'un tuzu olup, rüsûmat dairesince ecnebi tuzu olduğu iddia edilerek el konulmuş tuz ile ilgili cereyan eden davada Borokos, bu tuzların Lum'da beher yüz kıyyesinin yüz kırk kuruşa alıcısı varken Molla Abdi nâmında bir kimse bunların beher yüz kıyyesinin yüz yirmişer kuruşa olarak kendisine verilmesini teklîf ettiğini ancak bu tuzlar1 istediği fiyata alamadığı için Molla Abdi sonra pişman olursunuz diyerek bilahare bu tuzların ecnebi tuzu olduğuna dâir bazı ifâdede bulunduğu binaenaleyh bu tuz konusundaki ihtilafin bundan meydana geldiğini ifade

${ }^{55}$ BOA. İ.HR. 7523

${ }^{56}$ BOA. İ.MMS. 24/1071

${ }^{57}$ BOA. İ.DH. 42124

${ }^{58}$ BOA. MKT. NZD. 345/86 
etmiştir. Bunun üzerine bu meselenin halledilmesi için oluşturulan komisyonda Borokos'un iddiasının bütün bütün red ve tekzîbine elde kuvvetli bir delil bulunmadığı cihetle bu konudaki ihtilaf tamamen halledilemeyeceği için anlaşma yoluna gidilmesi tavsiye edilmiştir. Zapt olunan tuzun miktarı doksan sekiz bin iki yüz yirmi altı kıyyeden ibâret bulunmuş olmasıyla bu konuda vukû'a gelen bazı müzâkere üzerine iki tarafın uygun görmesiyle bahsedilen tuza mukabil olmak ve Borokos'un bundan sonra bu konuda hiçbir hak iddia etmemesi şartıyla kendisine Façitin ? mahallesinde meccânen ol-kadar yerli tuzu verilerek ihtilafın ortadan kaldırılmasına ittifakla karar verildiği bildirilmiştir ${ }^{59}$.

Müsâdere mekanizmasının işleyişinin mahiyeti yolsuzluklara son derece müsait idi. Müsâderede malları yazmakla görevlendirilen memur ile ilgili tek teminat onun dürüst olup olmamasıydı. Bu memurlar bazen malları kendi aralarında bölüşüp üçte birini bile hazineye göndermedikleri oluyordu. Ve bu memurların bu hali ihbar dışında bilinemiyordu. Bazen kadılar da mirasçılardan rüssvet alıp malları gizleyebiliyor. $\mathrm{Bu}$ da ancak bir ihbar neticesinde anlaşılabiliyordu ${ }^{60}$.

Bunun için birçok devlet adamı değişik zamanlarda yapılmakta olan keyfî müsâdereler üzerinde durmuş ve bunun devletin bekası için çok tehlikeli olduğuna dikkat çekmiştir. Osmanlı tarihinin buhranlı bir döneminde tahta çıkan III. Selim (1798-1807) döneminde müsâdere yönteminin 1slah edilmeye çalış1ldığ1 görülmektedir. Rusya ve Avusturya ile iki yıldan beri devam etmekte olan savaş Osmanlı maliyesini alt üst etmişti. Padişah bu krizi aşabilmek için devlet adamlarının da reyine başvurarak bir takım çareler aradıysa da başarılı olamadı. Sonunda bizzat işe girişerek para tedârik etmek istedi. Aklına gelen ilk tedbir ise müsâdere oldu. Ancak bu uygulama itirazlara uğrayınca itirazlara cevap olmak üzere neşrettiği bir hatt-1 hümâyûnda; niyetinin yetim malı ve kendi emeğiyle servet edinmiş kimselerin malına dokunmak olmadığını ancak sadece devlet kapısında zengin olmuş kimselerden ölenlere ait malların ne ölenin varislerine ne de sultanın kendisine ait olduğunu, bu malların din ve devlet uğrunda sarf edilmek üzere tamamen hazineye alınacağını belirterek, uygulamanın kendinden önceki padişahlar zamanında da farklı olmadığını belirtmişti ${ }^{61}$.

Müsâdere meselesinin çözüme kavuşturulması bir zarûret halini almıștı. Yeniçeri Ocağının kaldırılması üzerine 17 Haziran 1826 günü, ümerâ ve ulemâ toplantısından sonra tamim olunan fermanda Yeniçeri Ocağı'nın kaldırıldığı belirtildiği gibi müsâderenin de kaldırıldı̆̆ı ilan edilmiştir. II. Mahmud söz konusu fermanında "bundan böyle saltanatın millet için bir dehşet, bir korku kaynağı değil bir destek olmasını istiyorum. Bunun için kişinin malına devletçe el konulması geleneğini kaldırıyorum" demesine ve müsâderenin ancak kamu

${ }^{59}$ BOA. İ.MMS 52/2268

${ }^{60} \mathrm{Mumcu}$, a.g.e., s.159

${ }^{61}$ Öğ̈̈n, a.g.m., s.378,379; Ünal, a.g.m., s.105,106. 
malı olduğu mahkeme kararıyla saptanan servetlere uygulanması kuralını getirmesine rağmen müsâdere tamamen kalkmış olmuyordu ${ }^{62}$.

Daha sonra yolsuzluklara elverişli olan bu usul, devletçe kendisinden beklenen faydayı tam olarak sağlayamaması ve bu müsâdere uygulamalarının toplum üzerinde uyandırdığı olumsuz etkiler dikkate alınarak, Batı dünyasını iyi tanıyan ve o sırada hariciye nezaretini idare etmekte olan Mustafa Reşid Paşa 1838'de Bâbrâli'de vekillerle görüştükten sonra önemli bir teşebbüse girişti. Önce vergi adaletini sağladı. Rüşvet, angarya ve müsâderenin kaldırılmasını içeren önemli bir takım esaslar belirledi. Örnek ve tecrübe olarak Bursa ve Gelibolu'da emlâkler tahrire (yazım) bağlandı. Böyle bir sslahat projesinden hoşnut kalmayan II. Mahmud, Dahiliye Nazırı Âkif Paşanın teşviki ile, bu teşebbüsü durdurup, Reşid Paşayı Londra elçiliğine gönderdi. Ancak Reşid Paşa, II. Mahmud'dan sonra tahta çıan Abdülmecid'in geniş ölçüde güvenirliğini kazanarak reform konusunda, onu ikna etmeyi başarmış ve bu sayede Tanzimat Fermanı ilan edilmiştir ${ }^{63}$. Bu fermanda “... faraza birinin töhmet ü kabahati vukuunda anın veresesi ol-töhmet ü kabahatten beriyyü'zzimme olacaklarından anın malını müsâdere ile veresesi hukuk-1 irsiyyelerinden mahrum kilınmamak ve teb'a-i saltanat-1 seniyyemizden olan ehl-i İslâm ve millet-i sâire bu müsa'adât-1 şahânemize bilâ-istisnâ mazhar olmak üzere can ve Irz u namus ve mal maddelerinden hükm-i şer’i iktizâsinca kâffe-i memâlik-i mahrusemiz ahâlisine taraf-1 şahânemizden emniyet-i kâmile verilmiş ...” denilerek müsâderenin bir ceza şekli olarak kaldırıldığı ilan edilmişsir ${ }^{64}$. Tanzimatın ilanı başta Mehmed Ali Paşa olmak üzere birçok kendi menfaatini devletin menfaatinin önünde görenlerce hoş karşılanmamıştır. Hatta Mehmed Ali Paşa bu fermanı değiştirmek için Mustafa Reşid Paşa'ya altmış bin kise akçe ikramiye arz ettirmiş iken Reşid Paşa asla buna meyl etmemiştir. Bunun üzerine Mehmed Ali Paşa bu meblağı bazı padişah yakınlarına arz etmekle Reşid Paşa'yı Hariciye nezaretinden azl ile Edirne valisi nasb ettirmiştir ${ }^{65}$.

Ancak, incelenen belgelerde de görüldüğ̈ gibi Tanzimat Fermanıla müsâdere ceza olarak uygulanmaktan kaldırılmasına rağmen; gerek elde edilen haksız kazançlar ve gerek işlenen suçlara karşı emniyet tedbiri ve bedel (tazmin) olarak uygulanmaya devam etmiştir.

\footnotetext{
${ }^{62}$ Baysun, a.g.m., s. 672; Ünal, a.g.m., s106,107.

${ }^{63}$ Baysun, a.g.m., s. 673; Geniş bilgi için bak. Mümtaz’er Türköne, "Osmanlılarda Islahat ve Teceddüd”, Osmanl Ansiklopedisi, Ağaç Yay. İstanbul 1993, VI, s.33-51; Doğuştan Günümüze Büyü̈ İslâm Tarihi, XI, s.431-445.

${ }^{64}$ Doğustan Günümüze Büyük İslâm Taribi, XI, s.447,448.

${ }^{65}$ Geniş bilgi için bk. Reşat Kaynar, Mustafa Reşid Paşa ve Tanæְimat, TTK Yay., Ankara, 1954, s.380-387.
} 


\section{Sonuç}

Görüldüğü gibi tarihsel geçmişi çok eskilere dayanan ve birçok keyfî uygulamalara konu olan müsadere, bugün hukuki nitelik ve anlayış bakımından önemli bir yol katetmiştir. Çağdaş ceza hukuku, müsadereyi güncel hale getirerek, suçlulukla mücadele de önemli bir gelişme kaydetmiştir. Birçok kimsenin mal bildirimi zorunda olması ve elde edilen haksız kazançların sorgulanip müsâdere edilmesi bu konudaki kanun maddelerine dayandırılmaktadır. Bu uygulamalar esnasında dikkat edilmesi gereken husus bu konudaki daha önceki tecrübelerimiz de gözönüne alınarak yapılan hataların tekrarlanmaması, devletin menfaatlerinin, bütün şahsî menfaatlerin önünde tutulmasıyla birlikte ferdî teșebbüslerin önüne geçilmemesi için fertlerin can ve mal güvenliğinin sağlanması gerektiğidir. 


\section{Kaynakça}

* Başbakanlık Osmanlı Arșivi, Hatt-1 hümâyûn , 233/13006.

* BOA. HH, 185/8647.

* BOA. HH, 194/9551.

* BOA. HH,104/4091.

* BOA. HH, 469/22908.

* BOA. HH, 524/25595.

* BOA. HH, 502/24653.

* BOA. HH, 520/25423.

* BOA. HH, $11 / 3580$.

* BOA. Mektûmi Mühimme Kalemi, 381/82 .

* BOA. A.MKT. MHM 440/70.

* BOA. A.MKT. MHM 464/46.

* BOA. Sadâret Husûsî Maruzat Kalemi, 165/153.

* BOA. Yildiz.Perakende, 2B.1/67.

* BOA. Mektûmî Kalemi-Umûm Vilâyet, 5/49.

* BOA. Hariciye Mektumî, 42/87.

* BOA. Amedi Kalemi , 71/70.

* BOA. A.AMD. $78 / 30$.

* BOA. A.AMD, 79/63.

* BOA. İrâde Hariciye, 7523.

* BOA. İrade-i Meclis-i Mahsus, 17/748.

* BOA. İ.M.MS. 24/1071.

* BOA. İ.M.MS 52/2268.

* BOA. İrade Dahiliye, 42124.

* BOA. Mektûmî Kalemi Nezâret ve Devâir, 345/86.

* AKGÜNDÜZ, Ahmed. Osmanl Kanunnameleri ve Hukûkî Tablilleri, OSAV., İstanbul 1990, I.

* AnaBritannica, Ana Yay., İstanbul 2004, XVI, s.368.

* AVCI, Mustafa. Osmanlı Hukûkunda Suclar ve Cezalar, Gökkubbe, İstanbul 2004.

* AYDIN, Mehmed Akif. "Osmanlı'da Hukûk”, Osmanl Devleti Tarihi, Zaman Yay., İstanbul 1999, II.

* BARKAN, Ömer Lütfi. "Kanun-nâme” İ. MEB., İstanbul 1993, VI, s.185-196.

* BAYSUN, Cavit. "Müsâdere", IA, MEB., İstanbul 1993, IX, s.669-673.

* DEVELIOĞLU, Ferit. Osmanlıca-Türkçe Ansiklopedik Lügat, Aydın Kitap evi, Ankara 1984.

* Doğuștan Günümüze Büyü̈k İslâm Taribi, Çağ Yay., İstanbul 1992, II.

* EMECEN, Feridun. "Kuruluştan Küçük Kaynarcaya" Osmanl Devleti Tarihi, Zaman Yay., İstanbul 1999, I.

* ESEN, Hüseyin. "İslâm Hukûku Açısından Müsâdere" , D.E.Ü. İlabiyat Fakültesi Dergisi, S.XV, İzmir 2002, s.183-215.

* GEDİK, Doğan. “5237 Sayılı Türk Ceza Kanununda Müsâdere Sistemi Hakkında Genel Bir Değerlendirme”, wmw. bukuki.net, 09.03.2006.

* HALAÇOGLU, Yusuf. Osmanlilarda Devlet Teşkilatı ve Sosyal Yapı, TTK., Ankara 1996.

* İbn Âbidîn, Reddüll-Mubtâr, Terc. Mehmet Savaş, Şamil Yay., İstanbul 1985, XII.

* INALCIK, Halil. Osmanh Imparatorluğu, Eren Yay., İstanbul 1996.

*KARAMAN, Hayreddin. Mukayeseli İslâm Hukûku, İrfan Yay., İstanbul 1982, I. 
*KAYNAR, Reşat. Mustafa Reşit Pașa ve Tanæimat, TTK Basımevi, Ankara 1954.

* KÖKSAL, M. Asım. İslâm Taribi, İrfan Yay., İstanbul 1979, IX.

* Kur'ân,

* Meydan Larousse, Meydan Yay., İstanbul 1993, IX, s.154.

* MUMCU, Ahmet. Osmanli Devleti’nde Siyâseten Katl, Birey ve Toplum Yay., Ankara 1985.

* Mustafa Nuri Paşa, Netâicül-vukêat, Sad. Neşet ÇAĞGATAY, TTK., Ankara 1992, I.

* ÖĞÜN, Tuncay. "Osmanlı Devletinde Müsâdere Uygulamaları", Osmanl, Yeni Türkiye, Ankara 1999, V. s.371-383.

* ÖZCAN, Hüseyin. Ansiklopedik Hukuk Sözlügü, Alfa, İstanbul 1993.

* SAYDAM, Abdullah. Osmanl Medeniyeti Taribi, Derya Kitap evi, Trabzon 1999.

* ŞAFAK, Ali. Hukuk Terimleri Sözlüğ̈̈, Rehber Yay., Ankara 1992,

* Solak-Zâde Taribi, Haz. Vahid Çabuk, Kültür Bakanlığ1 Yay., Ankara 1989, I.

* SURUÇ, Salih. Peygamberimizin Hayatı, Yeni Asya Yay., İstanbul 1991, II.

* Şemseddin Sami, Kamûs-ı Türkê, Çağrı Yay., İstanbul 1996.

* ŞEN, Murat. "Osmanlı Hukûkunun Yapısı", Osmanl, Yeni Türkiye, Ankara 1999, VI, s. 327-339.

* TÜRKÖNE, Mümtaz'er. "Osmanlilarda Islahat ve Teceddüd”, Osmanl Ansiklopedisi, Ağac Yay., Istanbul 1993, VI.

* ÜNAL, Mehmet Ali. “Osmanlı İmparatorluğu'nda Müsâdere” Türk Dünyası Araşttrmalar Dergisi, Ağustos 1987, S. 49, s.95-111.

*........... Osmanli Müesseseleri Taribi, Isparta 1997.

*YEDIYILDIZ, Bahaeddin. XVIII. Yüzynlda Türkiyede Vakıf Müessesesi, TTK Basımevi, Ankara 2003.

*YEĞİN, Abdullah. Yeni Lügat, Hizmet Vakf1 Yay., İstanbul 1978.

* YÜKSEL, Hasan. Osmanl Sosyal ve Ekonomik Hayatında Vakeflarm Rolü (1585-1683), Sivas 1998.

* Zeynüddin Ahmed. b. Ahmed, Sabîh-i Bubârî Mubtasar Tecrîd-i Sarih Tercemesi ve Şerbi, Diyanet İş.Baş. Yay., Ankara 1980, VIII, s. 36,37. 